\title{
THE STRATEGY OF ISLAMIC CHARACTER EDUCATION WITH ROLE MODEL AND HABITUATION METHOD ON ONLINE LEARNING
}

\author{
Rony Sandra Yofa Zebua ${ }^{1}$, Sunarti ${ }^{2}$ \\ ${ }^{1}$ Magister Pendidikan Islam, Universitas Islam Bandung \\ ${ }^{2}$ Sekolah Bisnis dan Manajemen, Institut Teknologi Bandung \\ Email: ${ }^{1}$ ronysyzebua@gmail.com, ${ }^{2}$ sunarti@sbm-itb.ac.id
}

DOI: $10.29313 /$ tjpi.v9i2.6875

Submitted: October, 26 ${ }^{\text {th }}$ 2020. Accepted: February, 16 th $^{\text {th }}$ 2021. Published: March, $11^{\text {th }} 2021$

\begin{abstract}
Massive development in technology has enforced the educational system to be able to adjust its activity. While maintaining conventional learning environment in character education is challenging, online learning environment provides different characteristics that require distinct strategies to meet the learning objectives. It requires different syntax to implement learning methods for character education on online setting. However, previous studies rarely discussed about character education syntaxes for online learning. Thus, this study aimed to fill the gap by synthesizing the syntax and strategies of implementing some learning methods in character education through online learning. It was chosen Islamic and Character Education as the subject and role model and habituation methods as the focus of the study. This study is a qualitative study using in-depth interview as data collection technique. The informants were teachers experiencing in implementing role model and habituation methods on online learning. The research findings showed that the general syntax of online learning is started from preparation, preliminary activity, core activity, closing, and strengthening activities. Preparation and strengthening activities are conducted in unscheduled time while the other activities are conducted in scheduled time. The proposed syntax is given but further studies are required to testify the syntax for different situations.
\end{abstract}

Keywords: Character Education, Islamic Education, Habituation Method, Role Model Method, Syntax

\begin{abstract}
ABSTRAK
Perkembangan pesat dalam teknologi telah mendorong sistem Pendidikan untuk dapat menyesuaikan diri. Ketika mengkondisikan lingkungan belajar dalam pendidikan character dalam lingkup pendidikan konvensiona memiliki tantangan tersendiri, pengkondisian lingkeungan belajar daring membutubkan strategi yang berbeda untuk, pencapaian tujuan pembelajaran. Diperlukan sintaks yang berbeda untuk menerapkan metode-metode pembelajaran untuk pendidikan karakter secara daring. Namun dari penelitian terdabulu jarang ditemukan penelitian yang fokus membahas tentang sintaks metode pembelajaran dalam pendidikan karakter secara daring. Oleb karena itu, penelitian ini bertujuan untuk mensintesa sintaks dan stategi dalam menerapkan beberapa metode pembelajaran yang populer digunakan dalam pendidikan karakter. Fokus penelitian ini adalah Pendidikan Karakter Islami dalam mata pelajaran Pendidikan Agama Islam dan Budi Pekerti dan metode yang diinvestigasi adalah Metode Keteladanan dan Habituasi. Penelitian ini merupakan penelitian kualitatif yang menggunakan teknik wawancara mendalam untuk. mengumpulkan data. Informan adalah guru-guru yang berpengalaman dalam menerapkan Metode Keteladanan dan Habituasi dalam pembelajaran daring. Dalam penelitian ini ditemukan babwa sintaks umum dimulai dari persiapan, pendabuluan, aktivitas utama, penutupan dan aktivitas penguatan. Aktivitas Persiapan dan penguatan dilakukan pada waktu yang tidak terjadwal, sedangkan aktivitas yang lain dilaksanakan pada waktu yang terjadwal pada jam pembelajaran. Penelitian lebih lanjut diperlukan untuk pengujian sintaks di berbagai situasi di sekolah yang berbeda.
\end{abstract}

Kata Kunci: Pendidikan Karakter, Pendidikan Agama Islam, Metode Habituasi, Metode Keteladan, Sintaks 


\section{INTRODUCTION}

The dynamicity of life and development of technology enforced the educational system to be able to adjust its activity (Ally, 2019: 312; Rahmawati, 2018: 245), especially on online technology as a new environment which has been significantly influencing human life (Priatmoko, 2018: 232). The character education system as the core part of education cannot be separated from online technology because the students themselves are the digital generation (Sumardianta \& Kris, 2018). It seems that the digital generation are more motivated with activities provided by online technology (Komalasari \& Saripudin, 2017: 184; Mertasari, 2016: 686), making them causing high dependence on such sophisticated breakthrough (Ormiston, 2011; Tapscott, 2009: 6-7). Therefore, the associated stakeholders or education actors, especially on character or Akblak (moral) education, are supposed to accept this condition and thoroughly prepare themselves to be ready for this era (Rahmawati, 2018: 253).

Character or moral education actors should understand the relationship and the bonding of the students to the online technology which is inevitable (Ally, 2019; Sakti, 2020; Sumardianta \& Kris, 2018). Thereby, character education is enforced to take the benefits from the online technology in developing, nurturing, and strengthening good moral or character as its main objectives (Amri, 2018; Sugiarti, 2011: 149-150; Sumardianta \& Kris, 2018 : 15). It indicates that the educators should endeavour to have strategy and competence to organize character education through online learning (Ally, 2019; Jensen, 2016: 13).

Character is an essential picture (Bennis, 2004: 144) embedded in individual mind (Zuchdi et al., 2012: 16) that determines the individuals fundamentally (Covey, 2004: 103).
Character is mind condition which is reliable in responding any situation in moral way (Lickona, 1991: 51) and enforce individual to do certain behavior spontaneously (Josephson \& Hanson, 2004: 4; Nata, 2016: 249).

The term of the character itself has a broadened scope, one of which is akblak (Tafsir, 2018: 65; Yaumi, 2018: 36; Zuchdi et al., 2012: 16) or moral (Lickona, 1991: 39) embedded in individuals (Mustoip, Japar, \& Zulela, 2018) based on their religious belief (Al-Mishri, 2018: 10; Tafsir, 2018: 65). Therefore, Islamic character can be defined as a moral built upon values from Islam, which is commonly called as Akblak Terpuji (commendable moral). The essence of Islamic character is presented in faith and piety to Allah, doing good things and being fair to themselves, fellow human, and also their environment while also avoiding them from doing badness, either in verbal or action (Al-Mishri, 2018: 18; Megawangi, 2004: 95; Zuchdi et al., 2012: 16).

The personal character can be changed and formed (Daradjat, 2018: 6061) by guidance from knowledge, practice, and habituation conducted constantly (AlQasimi, 2010: 304-305; Zebua, Ihsan, \& Nurjanah, 2020: 123). This is the essence of hadith transmitted by Imam Muslim no. 2658 (Al-Atsari, 2006: 13; Daradjat, 2018: 61) and al-Quran surah Asy-Syams, 8-9 (Daradjat, 2018: 61; Ibnu Katsir, 2004: 479-480). According to Ibn Miskawaih (1398 H as cited as Mu'minah, 2015: 103), the character is not heredity, but is able to be generated, so that the development of individual behavior is started from innate potential combined with the effect from the environment (Al-Qasimi, 2010: 311; Tafsir, 2018: 45). All the affecting variables establish reciprocal relationships in determining individual behavior change (Dewar, Lubans, Plotnikoff, \& Morgan, 2012; Santrock, 2011: 235-236; Schunk \& DiBenedetto, 2020). 
In character education, the conditioning environment plays a vital role (Bandura, 1999; Schunk \& DiBenedetto, 2020: 5). Consequently, educators are challenged to be able to provide an educational environment which is required to stimulate the development and improvement of students' behavior (Alhamuddin \& Bukhori, 2016: 32; Zebua, 2020: 196). Some strategies to apply are such as providing a role model or an exemplar and structured habituation implemented in character education (Santrock, 2011: 237).

Role model method and habituation are fundamental and most popular methods in character education (e.g. Idharudin, Alim, \& Al Kattani, 2019; Pertiwi, 2018; Sahroni \& Latief, 2019). Role model method is a process to give example on a certain behavior where the students can directly see and imitate them (Abdillah \& Syafe'i, 2020: 24). Meanwhile, habituation is a process of development or improvement of certain habits through iterative experience (Shoimah, Sulthoni, \& Soepriyanto, 2018: 172). Both methods are expected to be implemented on online learning.

Online learning is distance learning where the interaction is created through internet network (Anderson, 2011; Mustofa, Chodzirin, \& Sayekti, 2019: 153). The characteristics of the interaction given by online learning offer fundamental differences if compared to face-to-face learning in class (Hass \& Joseph, 2018; Wuensch, Aziz, Ozan, Kishore, \& Tabrizi, 2008; Zebua, 2020). Therefore, educators should have expertise and strategy to implement the methods through online (Wang et al., 2019).

There are distinct syntaxes required to enable the educators implementing role model and habituation methods on online learning properly. However, according to previous studies focusing on developing Islamic character on Islamic and Character Education subject (Mata Pelajaran Agama
Islam \& Budi Pekerti), which is commonly called PAI subject, it is not yet found syntaxes from both methods for online learning. The existing literature mainly focused on the essence and benefits of role model and habituation methods (e.g. Idharudin et al., 2019; Meng \& Muñoz, 2016; Sahroni \& Latief, 2019). There were found studies analysing the syntaxes of the methods implemented PAI subjects (Nuroni \& Khambali, 2016; Nurussalami, 2017; Syamsir, 2017) and character education (Pertiwi, 2018; Saifuddin, 2018), but the context was commonly in face-toface class. Another study has focused on syntaxes in character education on online learning, but it was still in general context (Zebua, 2020).

Therefore, this study aimed to identify and synthesize the syntaxes and strategies of implementing role model and habituation methods in character education of PAI subject through online learning. This study is expected to be an alternative solution and perspective for educators to present educative interaction in character building on online learning. In addition, this study can be one of the references for more comprehensive development of character education through online.

\section{RESEARCH METHOD}

This study is a qualitative study using in-depth interview as the technique of data collection, in which informants were chosen through purposive sampling (Sugiyono, 2018: 301). The informants were PAI teachers who have experience in implementing role model and habituation methods on online learning and have interests and strong determination in doing learning activities through online as maximum as possible.

The interview processes were conducted on $24^{\text {th }}-28^{\text {th }}$ August 2020. The interviewed teachers were from 3 different school grades, from Junior High Schools 
to Senior High Schools. The data of all informants are presented in Table 1.

Tabel 1.Informant Data

\begin{tabular}{ll}
\hline Informant & Specification \\
\hline Teacher 1 & PAI teacher on X \& XII class at \\
& SMAN 1 Kedung Waringin, \\
& $\begin{array}{l}\text { Bekasi District, who has } 10 \text { years } \\
\text { of teaching experiences }\end{array}$ \\
\hline Teacher 2 & PAI teacher on VII \& IX class at \\
$($ G-2 $)$ & SMP Mutiara Bunda Bandung, \\
& who has 4 years of teaching \\
& experience, being occupied as Vice \\
Teacher 3 & PAIncipal teacher on VII class at SMP \\
$($ G-3) & YPAI Rahayu Bandung and XI \& \\
& XII class at SMK KP 2 \\
& Margahayu, who has 7 years of \\
& teaching experience, being \\
& occupied as a principal at SMP \\
& YPAI Rahayu Bandung \\
\hline
\end{tabular}

The data gathered was then analysed using directed qualitative content analysis technique (Directed QCA) because it was used a theory of character by Lickona as the main framework of the analysis process (Mayring, 2014). The step-by-step methodology conducted for this research is presented in Figure 1.

Figure 1. Research Methodology

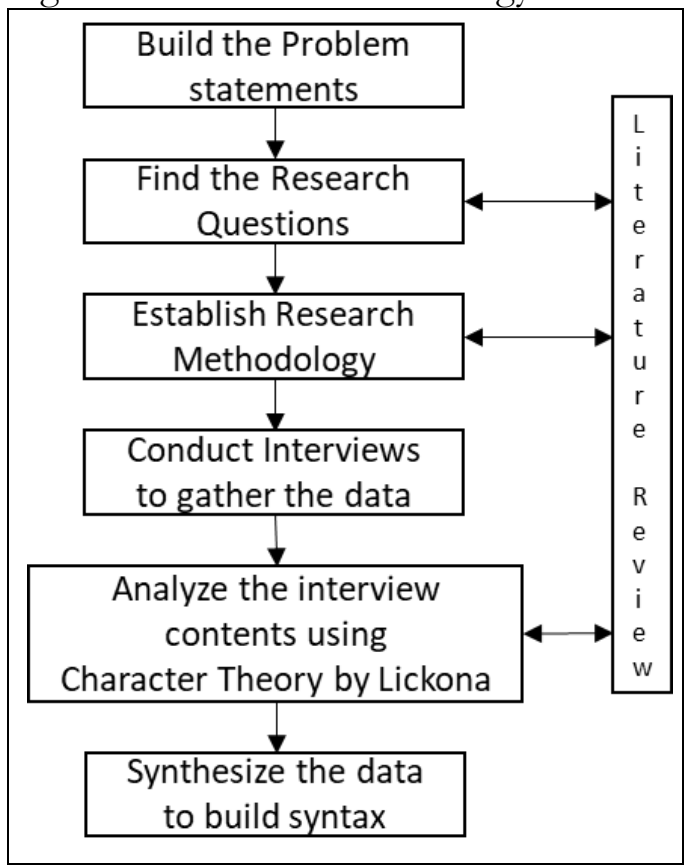

\section{RESULT AND DISCUSSION}

The interactions created on online learning when implementing role model and habituation methods will be different if compared to traditional learning (faceto-face learning). Online interactions are created by utilizing digital peripherals and particular applications connected to internet network (Mustofa et al., 2019: 153). According to Informants G-1 and G-3, it is still possible to get intensive interaction through online learning. In fact, it is not limited only on the scheduled time. The interactions created are highly dependent on the creativity and interests of the teachers (Ally, 2019; Rahmawati, 2018). The informants stated that the implementation of the learning activities is adjusted to the student's condition and the capacity of the internet connection. In this case, it requires parents' understanding and cooperation.

Generally, every method has three phases: preliminary phase, core phase, and closing (Fatimah \& Usman, 2017: 16-17; Nurussalami, 2017: 129). Besides, it is found that learning activities are also conducted outside of the scheduled time. The similarity is that there are two similar steps for every learning activity: opening and closing the learning activity with the greeting and praying.

\section{Role Model \& Habituation on Online Learning in SMAN 1 Kedung Waringin, Bekasi}

The learning activities using role model and habituation conducted for PAI subject in SMAN 1 Kedung Waringin were conducted within scheduled and unscheduled time through Whatsapp and Google Classroom. Role model method in scheduled learning time was started through the following steps (1) the teachers showed neat outfit and friendly attitude by showing their photo taken just before the learning activities started, (2) 
The teachers gave an article about mandatory of learning, (3) The teachers told the students about a role model or piety stories contextually and briefly, (4) The teachers gave learning materials through writing and voice recording which are related to role model with interesting, brief and contextual way, (5) The learning activities were closed through writing about commendable morals or role model. These steps are the potential to nurture attention and value knowledge storing (Santrock, 2011). Besides, it will stimulate conscience, self-esteem and loving the good (Lickona, 1991).

Meanwhile, habituation activities in scheduled learning activities were (1) the teachers motivated the students using polite language, neat apparel, discipline and doing piety, (2) The teachers gave learning materials that enabled the students understand about how to do certain behaviors or worship, (3) the learning activities were closed by writing on the platform to encourage the students to practice praiseworthy morals. The strategy in the habituation method helps the students to have the ability and willingness to embody the expected behaviors (Enderle et al., 2018; Lickona, 1991).

The activities conducted outside the scheduled time at SMAN 1 Kedung Waringin were done without time limit. The interactions were done personally or through group on the apps. The activities embedded in the role model unsure were (1) The teachers shared stories or examples of role models or piety through writing, photos, and voices; (2) The teachers asked the students to be interactive toward the stories given; (3) The teachers showed several worship activities to motivate the students to do certain activities, such as tabajud prayer; (4) The teachers stimulated students' conscience by exemplary words such as "an old and busy teacher is still able to wake up in the middle of the night and in the dawn, you are supposed to be able to do better". For the activities outside the scheduled time, the learning activities containing habituation methods were for instance, when the teachers wake the students up in the middle of the night to encourage them praying tabajud, and then make a list in the Whatsapp to identify students who have conducted the prayer.

The mentioned activities if conducted intensively and iteratively will help the student to keep learning from the teachers (Ormrod, Anderman, \& Anderman, 2017: 351). This activity will nurture motivation (Schunk \& DiBenedetto, 2020), so that, eventually will nurture conscience, self-esteem, empathy, and willingness to do it (Lickona, 1991). Besides, it is able to nurture selfefficacy required to convert it to be behavior (Ormrod et al., 2017; Santrock, 2011).

\section{Role Model and Habituation on Online Learning in SMP Mutiara Bunda Bandung}

The online learning for PAI subject in SMP Mutiara Bunda Bandung utilized Google Meet. The evaluation process was conducted through Quirizz and Kahoot so that the process was real-time and avoided giving the answer through the photo. The activities of the role model method in scheduled activities are the following: (1) The teachers started the learning activity by activating the camera on throughout the learning hours to enable students to see the teacher's appearance. Therefore, the teachers showed themselves in discipline and neat appearance, (2) The teachers reminded the students about the role model materials which have been discussed beforehand, (3) The teachers told the student to do worship such as dhuba prayer in the morning and reading Quran before starting the learning, (4) The materials given were related to interesting role model presented through interactive 
videos, (5) The teachers closed the learning activities by reminding the students about the materials just given.

The habituation activities in the scheduled learning were (1) Students turned on the video to show their neat appearance during the learning process, (2) The teachers always asked the students to do dbuba prayer and reading Quran before starting the learning, (3) The learning process was recorded and there was a team to accompany the teachers to supervise the students' behavior, so that the students get used to be motivated and show nice attitude during the learning process, (4) The teachers closed the learning activities by persuading the students to implement the materials have been learned.

The unscheduled activities only contain habituation method. The habituation implementation conducted and evaluated through Behavioral Report which were fulfilled by the parents and the students, and then being evaluated by the teachers every week.

The mentioned steps can attract students' attention and encourage them to be maximal in storing value knowledge (Ormrod et al., 2017: 251), because it is considered to be able to develop interesting and fun learning climate (Ally, 2019; Amri, 2018). However, environmental conditioning for role model and habituation method implemented in unscheduled times is still limited.

\section{Role Modal and Habituation on Online Learning in SMP YPAI Rahayu Bandung}

Learning activities for PAI subject conducted online in SMP YPAI Rahayu Bandung were conducted through Whatsapp. Google Classroom was also utilized but only for saving learning materials and task application. Preliminary activities for every method in scheduled activities have the same syntax, such as (1) After greeting, the teachers always reminded the students and revived them that Allah always supervise everyone. To do this, the teachers used voice note, (2) The teachers asked students' readiness (3) The teachers gave the learning materials and the learning objectives through writing, (4) The teachers asked students' worship activities. For closing, the syntax conducted are (1) the teachers reminded them about Allab's surveillance, and (2) The teachers asked the students to keep their worship and their good behavior.

The core activities of role model method were conducted in the scheduled learning were (1) The teachers gave role model materials through videos, (2) the teachers encouraged the students to discuss about the video, (3) and then wrote the conclusions. The utilization of video is expected to stimulate the students (Sumardianta \& Kris, 2018), which eventually make the students interested in paying attention to it (Santrock, 2011). Once the students interested, it improves its probability to internalize the behavior (Ormrod et al., 2017).

The core activities of the habituation method in SMP YPAI Rahayu Bandung was also conducted outside the scheduled time. The activities conducted by using daily journal fulfilled by the students and being supervised by the parents. The general strategies conducted were (1) the teachers asked and reminded the students to keep their worship and good behavior continuity, (2) the teachers always reminded the students about Allab's supervision, (2) the teachers reminded the students to fulfil the daily journal, (3) the teachers checked the daily journal fulfilled by the students gradually, (4) the teachers asked about the validity of the journal fulfilment to the students and parents through Whatsapp personally.

The strategy of habituation method conducted in SMP YPAI Rahayu Bandung was more focused on personal interest 
development. The students are motivated through emphasis on the feeling that they are supervised by Allah. The internalization in this process will encourage learning spirit and responsibility as well as honesty (Schunk \& DiBenedetto, 2020).

\section{Common Syntax of Role Model and Habituation Method on Online Learning}

Based on the findings previously explored, it is identified the syntax for role model and habituation method on online learning is grouped into 5 phases, as presented in Figure 2. The phases are preparation, preliminary, core activity, closing and strengthening (Zebua, 2020). The evaluation activity is integrated in the core and strengthening activity. The 5 phases are conducted to fulfil the aspects of attention, retention, production, and motivation. (Santrock, 2011).

Figure 2. General Syntax (modified from Zebua, 2020)

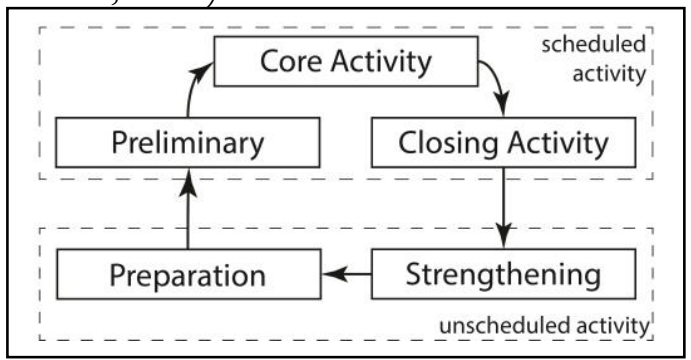

The general syntax of the activities in the scheduled learning activities are preliminary, core activity, closing activity. Generally, the primary interactions in the learning process are through instant messenger applications such as Whatsapp or conference video such as Zoom Meeting. Both applications have different characteristics (Tapscott, 2009), thus the syntax are different.

The preliminary phase and strengthening are conducted on unscheduled time. Therefore, the activities are conducted informally. The strengthening phase is conducted using more flexible strategy and more maximising online technology utilization. Thereby, the activities are not tightly bonded to the ordered syntax. However, the concept keeps clear. The flexible and maximum use of technology in learning will make the students more interested and more motivated (Sumardianta \& Kris, 2018; Tapscott, 2009). Even though conducted online, the expected activities will ease the students to learn directly from the teacher and habituating toward new certain behavior (Ormrod et al., 2017).

\section{Preparation Phase on Online Learning}

Good preparation before learning activities will help the students to be more concentrated and also cultivate students' self-efficacy to involve the learning activities (Ormrod et al., 2017). The preparation phase can be done one day before or at least one hour before the learning activities. The preparation step utilizes Whatsapp and the like.

The syntax in preparation phase is (1) the teachers remind and motivate the students about learning obligation using voice note, (2) the teachers give learning materials and divide students group briefly and clearly. If using video conference application, the teachers determine which students or group of students who fulfil the preliminary activities such as puzzles, (3) the teachers encourage the students keep attention and allow the students to ask questions, (4) Before the learning activities, the teachers remind the students to prepare themselves, keep clean, and neat.

\section{Preliminary Phase on Online Learning}

Preliminary activities are supposed to bring the students to be interested and more challenged toward the learning (Joyce, Weil, \& Calhoun, 2015). Generally, 
preliminary activities for every method has no difference.

The syntax in preliminary phase depends on the application used. The syntax in this phase for Whatsapp are (1) the teachers greet the students and motivate them, (2) the teachers ask the student to fill out the presence list, using various tools such as Google Form (3) while waiting for the presence list, the teachers send photos about presence and neatness while ask the students to do the same things, (4) then, the teachers ask the students to keep doing their worship, well behaved and carry out the learning materials as maximum as possible, (5) the teachers remind the students about Ibsan and honesty.

Syntax in preliminary phase for Zoom Meeting are (1) the teachers are online on time with neat apparels, (2) the teachers greet the students and ask the students to keep activating their camera on during the learning hours, (3) the teachers greet the students one by one, ask and motivate them to do their worship and well behaved regularly, while also keep their well dressing and learning attitude, (4) the teachers ask the students or the group of the students to give simple puzzles. All the activities conducted use clear language and tenderly.

\section{Core and Closing Activity Phase of Role Model Method on Online Learning}

The syntax for role model method is supposed to ease the students to learn directly to the teachers or to the stories given by the teachers (Ormrod et al., 2017). Thus, the teachers should have the required skills and also good characters to give a good role model maximally (Schunk \& DiBenedetto, 2020; Zebua et al., 2020). Besides, there should be conditioned environments that support the principles reaching moral feeling aspects (Lickona, 1991).
In most cases, the syntax for core activities on role model method on online learning contain a number of activities: (1) the teachers share presentation file (using instant messenger application) or exposing the presentation through video conference apps, (2) the teachers remind the students about wisdom from the learning materials given previously, (3) the teachers persuade the students to watch the role model- material videos, (4) the teachers persuade the students to discuss the contents while also telling them about the wisdom and the connection of the materials to the learning materials, (5) the teachers expose different examples and stimulate the students for comparison. The syntax in the core activities are flexible for the sequence (Joyce et al., 2015).

For closing activities: (1) the teachers review the learning briefly and give conclusions, (2) the teachers motivate and encourage self-confidence for the students to conduct the expected behavior, (3) the teachers tell the student that they also practice the worship and well behaved. The essence of the closing activities is to motivate the students to do the expected behavior (Santrock, 2011; Schunk \& DiBenedetto, 2020).

\section{Core and Closing Activity Phase of Habituation Method on Online Learning}

The syntax for habituation method should facilitate the students to develop their competence and motivation to do it (Lickona, 1991; Lickona, Schaps, \& Lewis, 2007). Besides, the conditioned environment should support production principle (Santrock, 2011). In this regard, the teacher is not only an instructor but also a counsellor that is able to maximize the students' competence and potency (Alhamuddin \& Bukhori, 2016).

Generally, the scopes of the syntax in this phase are (1) the teachers persuade 
the students to tell their obstacles in adjusting to the expected worship or behavior, (2) the teachers share videos or pictures about the expected worship or behavior, and encourage the students to watch them, (3) the teachers persuade the students to discuss about the videos or pictures and ask them to tell their opinion, (4) the teachers persuade the students to practice it, (5) the teachers tell the students to send the documentation of their practice through instant messenger applications or show them directly using video conference app. This activity aims to encourage the students to give evidence while also stimulate the students to try it (Joyce et al., 2015).

The closing activity can be done through the following steps: (1) the teachers give a brief review and conclusion, (2) the teachers persuade the students to get used to doing the behavior, (3) the teachers persuade the students to fill out daily activity report in the Google Form once they have practiced it. The essence of this closing activity is to enable students to have the competence and get used to it (Lickona, 1991).

The Strategy of Role Model and Habituation Strengthening on Online Learning

The activities in strengthening phase are conducted dynamically and nonformal. It needs parents' understanding and cooperation to maximize the strategy (Abdillah \& Syafe'i, 2020; Nuroni \& Khambali, 2016). Based on the findings, this study proposes the integrated strategy for role model and habituation method.

The strategy is implemented using instant messenger applications for interaction activity and Google Form or the like, for daily journal. The daily journal is not for fardhu worship that requires exact time. The steps of the strategy: (1) the teachers persuade and remind the students to fill out the daily journal along with the documentation, (2) the teachers remind the students to do worship and well behaved through sending inspiring stories in the form of video, photos or writings, (3) the teachers ask students' respond toward the stories given, (4) the teachers report every worship and daily activities conducted by the teachers through videos or photos, (5) the teachers remind the students to do the worship through Whatsapp group exactly in the time when the worship should be done, (6) and ask the students to report their practice once they have done it, through Whatsapp group using voice note, (7) give their Quran memorization through voice note on the determined time. Meanwhile, the teachers keep reminding the students about Allah's supervision.

\section{Evaluation Strategy}

The evaluation activities are integrated into the core and strengthening activity. Basically, the evaluation is conducted by observing students' involvement in the core and strengthening activities. Besides, summative evaluation is still conducted using Quizizz or Google Form and the like.

\section{CONCLUSION}

This study found the syntax as the strategy to implement character education on online learning using two popular methods: role model and habituation method. Both methods can be implemented on online learning using the appropriate steps. However, it needs willpower, interest, and competence from the teachers to implement it properly. The teachers should have the capability to present a role model and habituation through the correct syntax and strengthening activities.

The research findings showed that the general syntax of online learning is started from preparation and followed by 
several steps that represent preliminary, core, closing, and strengthening activities. Preparation and strengthening activities are conducted in unscheduled time while the other activities are conducted in scheduled time.

According to the information given from the teachers' experience, this study provides alternative syntax to implement role model and habituation model through online learning. The activities in the syntax and strengthening activities can be implemented directly or adapted by the PAI teachers or character teachers to the adjusted situations. Further studies can be focusing on the testing of the syntax and strengthening activity to the various schools for syntax robustness.

\section{BIBLIOGRAPHY}

Abdillah, A., \& Syafe'i, I. (2020). Implementasi Pendidikan Karakter Religius di SMP Hikmah Teladan Bandung. Jurnal Pendidikan Agama Islam, 17(1), 17-30. https://doi.org/10.14421/jpai.2020. 171-02

Al-Atsari, A. bin A. H. (2006). Intisari Aqidah Ablussunnah wal Jama'ah. Jakarta: Pustaka Imam Asy-Syafi'.

Al-Mishri, M. (2018). Ensiklopedi Akblak Rasulullab Jilid 1 (Solibin Rosidi \& Mubammad Misbah, penerjemah). Jakarta: Pustaka Al-Kautsar.

Al-Qasimi, J. (2010). Buku Putih Ibya' Ulumuddin Imam Al-Ghazali. Bekasi: Darul Falah.

Alhamuddin, \& Bukhori. (2016). The Effect of Multiple Intelligence-Based Instruction on Critical Thinking of Full Day Islamic Elementary Schools Students. Ta'dib, 21(1), 31-40. https://doi.org/10.19109/td.v21i1.5 90

Ally, M. (2019). Competency Profile of the Digital and Online Teacher in Future Education. International Review of
Research in Open and Distance Learning, 20(2), 302-318. https://doi.org/10.19173/irrodl.v20 i2.4206

Amri, M. (2018). Islam dan Pendidikan Karakter dalam Framing Media Online. Ta'dib: Jurnal Pendidikan Islam, 7(1), $\quad$ 445-453. https://doi.org/10.29313/tjpi.v7i1.3 802

Anderson, T. (2011). The Theory and Practice of Online Learning. Edmonton: AU Press.

Bandura, A. (1999). Social Cognitive Theory: An Agentic Perspective. Asian Journal of Social Psychology, 2, 2141. https://doi.org/10.1111/1467839x.00024

Bennis, W. (2004). The Character of Leadership. In M. S. Josephson \& W. Hanson (Eds.), The Power of Character (2nd ed., pp. 142-149). Indiana: Unlimited Publishing LLC.

Covey, S. R. (2004). Growing Great Children. In M. S. Josephson \& W. Hanson (Eds.), The Power of Character (2nd ed., pp. 98-107). Indiana: Unlimited Publishing LLC.

Daradjat, Z. (2018). Ilmu Pendidikan Islam. Jakarta: Bumi Aksara.

Dewar, D. L., Lubans, D. R., Plotnikoff, R. C., \& Morgan, P. J. (2012). Development and Evaluation of Social Cognitive Measures Related to Adolescent Dietary Behaviors. International Journal of Behavioral Nutrition and Physical Activity, 9(36), 110. https://doi.org/10.1186/14795868-9-36

Enderle, C. de F., Silveira, R. S. da, Dalmolin, G. de L., LunardiI, V. L., AvilaI, L. I., \& Dominguez, C. C. (2018). Teaching Strategies: Promoting the Development of Moral Competence in Undergraduate Students. REBEn: 
Revista Brasileira de Enfermagem, 71 (suppl 4), 1650-1657. https://doi.org/10.1590/00347167-2017-0704

Fatimah, N. E., \& Usman, N. (2017). Implementasi Pendidikan Karakter Dalam Pembelajaran Fiqih di MI Al Islam Tonoboyo Kecamatan Bandongan Kabupaten Magelang. Tarbiyatuna, 8(1), 9-22.

Hass, A., \& Joseph, M. (2018). Investigating Different Options in Course Delivery - Traditional vs Online: is There Another Option? International Journal of Information and Learning Technology, 35(4), 230-239. https://doi.org/10.1108/IJILT-092017-0096

Ibnu Katsir. (2004). Tafsir Ibnu Katsir Jilid 8. Bogor: Pustaka Imam Asy-Syafi'i.

Idharudin, A. J., Alim, A., \& Al Kattani, A. H. (2019). Penerapan Model Pendidikan Akhlak Syaikh Utsaimin di SDIT Al-Hidayah Bogor. Jurnal As-Salam, 3(3), 53-66. https://doi.org/10.37249/assalam.v3i3.137

Jensen, E. B. (2016). Peer-Review Writing Workshops in College Courses: Students' Perspectives about Online and Classroom Based Workshops. Social Sciences, 5(4), 1-17. https://doi.org/10.3390/socsci5040 072

Josephson, M. S., \& Hanson, W. (2004). The Power of Character (2nd ed.). Indiana: Unlimited Publishing LLC.

Joyce, B. R., Weil, M., \& Calhoun, E. (2015). Model of Teaching (9th ed.). New York: Pearson.

Komalasari, K., \& Saripudin, D. (2017). Value-Based Interactive Multimedia Development through Integrated Practice for The Formation of Students' Character. TOJET: The Turkish Online Journal of Educational
Technology, 16(4), 179-186.

Lickona, T. (1991). Educating For Character: How Our Schools Can Teach Respect and Responsibility. New York: Bantam Books.

Lickona, T., Schaps, E., \& Lewis, C. (2007). CEP's Eleven Principles of Effective Character Education. Washington: Character Education Partnership. Retrieved from https:/ / eric.ed.gov/?id=ED505086

Mayring, P. (2014). Qualitative Content Analysis: Theoretical foundation, basic procedures and software solution. Klagenfurt: SSOAR. https://doi.org/10.4135/978144628 2243.n12

Megawangi, R. (2004). Pendidikan karakter: Solusi Yang Tepat Untuk. Membangun Bangsa. Jakarta: Indonesia Heritage Foundation.

Meng, L., \& Muñoz, M. (2016). Teachers' Perceptions of Effective Teaching: A Comparative Study of Elementary School Teachers from China and the USA. Educational Assessment, Evaluation and Accountability, 28(2), 179-199.

https://doi.org/10.1007/s11092015-9230-9

Mertasari, N. M. S. (2016). Media Online Untuk Asesmen Pendidikan Karakter Terpadu. Jurnal Sains Dan Teknologi, 5(1), 683-691. https://doi.org/10.23887/jstundiksha.v5i1.8273

Mu'minah, N. (2015). Character Building Dalam Konsep Pendidikan Imam Zarkasyi Ditinjau Dari Filsafat Moral Ibnu Miskawaih. Filsafat, 25(1), 100133.

https://doi.org/10.22146/jf.12616

Mustofa, M. I., Chodzirin, M., \& Sayekti, L. (2019). Formulasi Model Perkuliahan Daring Sebagai Upaya Menekan Disparitas Kualitas 
Perguruan Tinggi. Walisongo Journal of Information Technology, 1(2), 151-160. https://doi.org/10.21580/wjit.2019. 1.2.4067

Mustoip, S., Japar, M., \& Zulela, M. S. (2018). Implementasi Pendidikan Karakter. Surabaya: Jakad Media Publishing.

Nata, A. (2016). Pendidikan dalam Perspektif Al-Qur'an. Jakarta: Kencana Prenadamedia.

Nuroni, E., \& Khambali. (2016). Implementasi Pembentukan Karakter pada Peserta Didik di MI Asih Putera Kota Cimahi. Ta'dib: Jurnal Pendidikan Islam, 5(1), 61-70. https://doi.org/10.29313/tjpi.v5i1.2 032

Nurussalami. (2017). Pengelolaan Pembelajaran Pendidikan Akidah Akhlak Pada MTsS Darul Aman Aceh Besar. Jurnal Intelektualita, 4(1), 123-139.

Ormiston, M. (2011). Creating a DigitalRich Classroom: Teaching \& Learning in a Web 2.0 World. Bloomington: Solution Tree Press.

Ormrod, J. E., Anderman, E. M., \& Anderman, L. (2017). Educational Psychology Developing Learners (9th ed.). Essex: Pearson Education Limited.

Pertiwi, P. L. (2018). Internalisasi NilaiNilai Toleransi Dalam Sistem Boarding School di Sekolah Menengah Pertama Islam Terpadu (SMP IT) Al Bashiroh TurenMalang. Jurnal of Peace Education and Islamic Studies, 1(1), 57-66.

Priatmoko, S. (2018). Memperkuat Eksistensi Pendidikan Islam Di Era 4.0. Ta'lim, 1(2), 221-239. https://doi.org/10.29062/ta'lim.v1i 2.948

Rahmawati, F. (2018). Kecenderungan Pergeseran Pendidikan Agama Islam di Indonesia Pada Era Disrupsi. TADRIS: Jurnal Pendidikan Islam, 13(2), 243-257. https://doi.org/10.19105/tjpi.v13i2. 1752

Sahroni, S., \& Latief, A. M. (2019). Program Evaluation - Strengthening Character Education In Integrated Islamic Junior Secondary School. JKP | Jurnal Kepemimpinan Pendidikan, 2(1), 152-164.

https://doi.org/10.22236/jkpuham ka.v2i1.3803

Saifuddin. (2018). Implementasi Pendidikan Nilai Melalui ActiveLearning Dalam Tradisi Pondok Pesantren An-Nur. CENDEKIA: Media Komunikasi Penelitian Dan Pengembangan Pendidikan Islam, 10(02), 171-182. https://doi.org/10.37850/cendekia. v10i02.74

Sakti, M. N. S. F. (2020). Moslem Social Media 4.0: Argumen Islam Terbadap Fenomena Sosial Media di Era Industri 4.0. Jakarta: Elex Media Komputindo.

Santrock, J. W. (2011). Educational Phychology (5th ed.). New York: McGraw-Hill.

Schunk, D. H., \& DiBenedetto, M. K. (2020). Motivation and social cognitive theory. Contemporary Educational Psychology, 60(101832), 110.

https://doi.org/10.1016/j.cedpsych. 2019.101832

Shoimah, L., Sulthoni, \& Soepriyanto, Y. (2018). Pendidikan Karakter Melalui Pembiasaan di Sekolah Dasar. Jurnal Kajian Teknologi Pendidikan, 1(2), 169175.

Sugiarti, Y. (2011). Peranan Teknologi Internet Dalam Membangun Pendidikan Karakter Anak. Jurnal Teknodik, 15(2), 145-154. 
https://doi.org/10.32550/teknodik. v0i0.97

Sugiyono. (2018). Metode Penelitian Kuantitatif, Kualitatif, dan Kombinasi (Mixed Method). Bandung: Alfabeta.

Sumardianta, J., \& Kris, W. (2018). Mendidik Generasi Z dan A. Jakarta: Grasindo.

Syamsir. (2017). Strategi Pembelajaran Guru Akidah Akhlak Dalam Pembinaan Akhlak Peserta Didik Di MI Al-Abrar Makassar. ALQALAM, 9(1), 123-138. https://doi.org/10.47435/alqalam.v9i1.256

Tafsir, A. (2018). Pendidikan Karakter Ajaran Tuban. Bandung: Remaja Rosadakarya.

Tapscott, D. (2009). Grown Up Digital: How the Net Generation is Changing Your World. New York: McGraw-Hill.

Wang, C., Hsu, H. K., Bonem, E. M., Moss, J. D., Yu, S., Nelson, D. B., \& Levesque-bristol, C. (2019). Need Satisfaction and Need Dissatisfaction: A Comparative Study of Online and Face-to-Face Learning Contexts. Computers in Human Behavior, 95, 114-125. https://doi.org/10.1016/j.chb.2019. 01.034

Wuensch, K. L., Aziz, S., Ozan, E., Kishore, M., \& Tabrizi, M. H. N. (2008). Pedagogical Characteristics of Online and Face-to-Face Classes. International Journal on ELearning, 7(3), 523-532.

Yaumi, M. (2018). Pendidikan Karakter: Landasan, Pilar, dan Implementasi. Jakarta: Kencana Prenadamedia.

Zebua, R. S. Y. (2020). The Strategy to Build Educative Interaction in Islamic Education on Online Learning Setting. Mudarrisa: Jurnal Kajian Pendidikan Islam, 12(2), 185-
202.

https://doi.org/10.18326/mdr.v12i 2.185-202

Zebua, R. S. Y., Ihsan, M., \& Nurjanah, N. (2020). Perkembangan Pendidikan Islam Periode Khulafāur Rāsyidīn dan Implikasinya Terhadap Pengembangan Pendidikan Islam di Indonesia. Jurnal Pendidikan Islam Indonesia, 5(1), 115-126. https://doi.org/10.35316/jpii.v5i1.2 28

Zuchdi, D., Kuntoro, S. A., Kunprasetya, Z., Marzuki, Isroah, Sukanti, ... Zamroni. (2012). Pendidikan Karakter: Konsep Dasar Dan Implementasi di Perguruan Tinggi. Yogyakarta: UNY Press. 